https://doi.org/10.38129/Ann.Yur.Ist.2020.4.4.30

УДК 343 (476)(091)

\title{
СТАНОВЛЕНИЕ И РАЗВИТИЕ НОРМАТИВНОЙ РЕГЛАМЕНТАЦИИ ПРЕСТУПЛЕНИЙ ПРОТИВ ЛИЧНОСТИ В СРЕДНЕВЕКОВОЙ БЕЛАРУСИ
}

\author{
ТАИСИЯ ДОВНАР (Минск, Республика Беларусь)*
}

На протяжении всей истории человечества правовые нормы, обеспечивающие охрану личности и свободы человека, их перечень и характер содержащихся в них запретов соответствовали общим началам организации общественно-экономической жизни той или иной эпохи. При этом длительный исторический период только нормы обычного права регулировали такие отношения. Даже с появлением писаного закона обычай еще долго конкурировал с законом, дополняя и иногда исправляя его1.

Как свидетельствуют летописные и другие известные нам письменные источники права Древней Руси - жизнь, здоровье свобода и честь человека охранялись вначале обычным правом, на смену которому постепенно приходил писаный закон. Отметим, что под Древней Русью нами понимается ряд княжеств, существовавших в древности на украинских, белорусских и российских землях. Например, в международных договорах Киевской Руси Х ст. (911, 944, 971 гг. и др.) за совершение подобных правонарушений в виде наказания устанавливались в основном штрафные санкции. В них упоминается также смертная казнь за убийство человека, хотя введение её в правовую материю Древней Руси произошло под влиянием византийского права несколько позже.

В отличие от византийской Эклоги, которая различала убийство предумышленное и убийство в драке, в договорах 911 и 944 гг. умышленное убийство не отличалось от неосторожного, а убийца подвергался смерти на месте преступления, хотя закон допускал выкуп или вознаграждение родственников убитого, если убийца скрывался ${ }^{2}$. При этом, соответственно

1 Доуннар Т. І. Развіцщё асноӱных інстытутау грамадзянскага і крымінальнага права Беларусі у̀ XV - XVI стагоддзях / T.I. Доуннар. Мінск: Пропилеи, 2000. С. 19.

2 Стешенко Л. А., Шамба Т. М. История государства и права России : Академический курс. В 2 т. Т.1. М.: Изд-во «НОРМА», 2003. С. 57. 
обычному праву, в рассматриваемый период в качестве наказания за убийство в основном предусматривалось применение кровной мести.

В Русской Правде - первом значительном памятнике Древней Руси содержалось небольшое количество статей, посвященных преступлениям и наказаниям против личности. При этом, в Русской Правде уже более заметно не столько влияние византийского права, как приспособление его к местным условиям. Так, Русская Правда не знала института смертной казни для свободных людей, хотя в реальной жизни таковая, несомненно, имела место. Умолчание о смертной казни многие ученые объясняют двумя обстоятельствами: законодатель принимал смертную казнь как продолжение кровной мести, которую стремился устранить, а также влиянием Церкви, которая в принципе выступала против смертной казни.

Следует подчеркнуть, что в указанный период четкого разграничения мотивов преступления и понятия виновности еще не существовало, хотя определенные дефиниции уже намечались. Так, одна из статей Русской Правды упоминает убийство «на пиру явлено», другая - «убийство «на разбое без всякой свары» 3 . Вместе с тем, в Русской Правде имели место представления о превышении пределов необходимой обороны (если вора убивали после его задержания и спустя некоторое время, когда непосредственная опасность от его действий уже не исходила), о понятиях умысла и неосторожности, рецидиве, смягчающих обстоятельствах (например, состояние опьянения), отягчающих обстоятельствах (корыстный умысел) и др.

Кроме убийства, преступлениями против личности по Русской Правде являлись: нанесение увечий (усечение руки, ноги), побоев, иных телесных повреждений и оскорбление. При этом от телесных повреждений следовало отличать оскорбления действием, которые наказывались еще строже, чем легкие телесные повреждения и побои. Так, в Краткой редакции Русской Правды содержались нормы об ответственности за преступления против чести и достоинства личности. Например, предусматривалась ответственность за оскорбление, выражающееся в повреждении бороды и усов. Кроме того, обнажение меча без его применения рассматривалось не просто как угроза, но и как оскорбление. Также в Пространной редакции Русской Правды предусматривалась ответственность, как за оскорбление (обиду), за удар человека мечом (если он не причинял телесного повреждения); а также за удар подручным предметом (батогом, чашей, рогом, ножнами меча).

${ }^{3}$ Исаев И. И. История государства и права России: учеб. 4-е изд. перераб. и доп. М., Проспект, 2010. С. 47. 
Дискуссионным остается вопрос относительно статьи 29 Краткой редакции Русской Правды, в которой предусматривалось наказание в виде штрафа за похищение («увод») холопа либо раба, т.е. несвободных людей. Некоторые ученые считают «увод» одной из первых попыток установления уголовной ответственности за посягательства на личную свободу человека и началом юридического оформления такого института 4 . По нашему мнению, несмотря на внешнюю очевидность направленности статьи на защиту личной свободы человека, по существу она была направлена на защиту собственности, каковой и являлся в то время несвободный человек.

Следует отметить, что Русская Правда не являлась единственным писаным источником права отмеченного периода. Одновременно и вместе с ней действовали и иные источники права, в которых заметно влияние византийского права.

Особо заметно это влияние, одновременно с приспособлением византийских законов к местным условиям в церковных уставах Владимира Святого и Ярослава Мудрого (конец X - начало XI вв.), представляющих собой «частную кодификацию норм церковного права, в которую были внесены санкции, заимствованные из Русской Правды» 5 . Так, устав Владимира очерчивал церковную юрисдикцию над всеми христианами по следующим деяниям: преступления против христианской веры и устоев Церкви; по всем семейным делам (иски о разводе, споры о наследстве и др.); преступления против христианской нравственности (о покушении на женскую честь, изнасилование, браки между ближайшими родственниками, оскорбление словом, необоснованное обвинение в преступлении (блуде, отравлении, ереси), убийство новорожденного, драка между супругами, нанесение побоев родителям, противоестественные грехи, скотоложство 6.

Князем Владимиром был издан, вместе с уставом или, возможно, вслед за ним «Закон судный людем», где в целом прослеживается тот же взгляд на преступление и наказание как и в Русской Правде, хотя размер наказания в ряде случаев несколько отличается. Нормы уголовного закона содержались также в Уставе князя Ярослава о церковных судах, который в своих определениях преступления и наказания представлял тот же взгляд, что и

4 Коротич Е. А. Преступления против личной свободы человека в ретроспективном аспекте / Е.А. Коротич // Вестник Полоцкого государственного университета. Серия D. Экономические и юридические науки, 2013. № 6. С. 197.

${ }^{5}$ Исаев И. И. Указ. соч. С. 35

6 Там же. С. 38. 
Русская Правда. В нем предусматривалась та же система денежных пеней и откупов, хотя и носившая несколько иной характер 7 .

В последующих нормативных актах, а в первую очередь в международных договорах XII-XIII вв., которые заключались также и белорусскими княжествами, встречаются уголовно-правовые нормы, сходные во многом с нормами Русской Правды.

Так, в Договоре 1229 года Полоцкого, Витебского и Смоленского княжеств с Ригой и Готским берегом регламентировалась уголовная ответственность (в основном денежные штрафы) за убийство, телесные повреждения, насилие над женщиной и др. При этом ответственность устанавливалась в зависимости от классовой принадлежности человека, например, за убийство свободного человека - 10 гривен серебра, за холопа - 1 гривна серебра. Закон различал тяжкие, менее тяжкие телесные повреждения и побои. За тяжкие телесные повреждения (повреждение ока, руки или ноги свободного человека) - 5 гривен серебра, за менее тяжкие (по уху ударит) - «три четверти серебра», а «послу и попу что учинять, за двое того узяти, два платежя» и т. Д. Устанавливалась также уголовная ответственность за прелюбодеяние - 10 гривен серебра, за изнасилование свободной женщины - 5 гривен серебра (если же «первее на ней сором был» - одна гривна серебра) и изнасилование несвободной женщины - одна гривна серебра 8 . В одном из случаев - «аже разгневается князе на своего человека», закон в качестве санкции предусматривал отнятие всего имущества этого человека и отдачу его жены и детей в холопство 9 .

Если в первых писаных законах древней Беларуси содержались только отдельные уголовно-правовые нормы, то в последующем в них можно увидеть определенную попытку законодателя сгруппировать нормы в определенной последовательности. Особенно прослеживается стремление законодателя установить единообразие в сфере уголовного и уголовно-процессуального законодательства в Судебнике Великого Княжества Литовского 1468 года, основу которого составляло, в первую очередь, обычное право древних княжеств. В тот период писаный закон еще не отменял обычаев (да и не мог этого сделать), а только дополнял их и в определенной степени

\footnotetext{
7 Российское законодательство X-XX веков. Т.1. Законодательство Древней Руси. С. 174.

8 Дагаворы і граматы як крыніцы беларускага феадальнага права: Дапаможнік. / Я. Юхо, А. Абрамовіч, Т. Доуннар, У. Сатолін. Мінск: БДУ, 2000. С. 37-39.

9 Там же. С. 38.
} 
систематизировал, придавая общегосударственный характер. При этом Судебник больше сосредоточивал внимание на имущественных преступлениях. В нем имелось лишь несколько статей, касающихся преступлений против личности.

Феодальный характер Судебника особо проявился в санкциях статей, предусматривающих смертную казнь через повешенье или телесные наказания, в том числе в статье, устанавливающей наказание в виде смертной казни за организацию побега челяди невольной и феодально-зависимых людей: «А который будеть люди выводит, а любо челядь невольную, а ухватять с лицом - того на шыбеницу» 10.

К преступлениям против личности можно несколько условно отнести регламентированные Судебником «порубы»и «наезды», т. к. во время их совершения (нападения на имения и пр.), как свидетельствуют судебные дела того периода, происходили убийства, телесные повреждения, иные насильственные действия. По существу их следует отнести к разбойным нападениям, однако в тот период разбоем считались аналогичные преступные деяния, однако совершенные «на дорозе». Вероятно, в связи с этим за совершение «порубов» и «наездов» закон регламентировал весьма неопределенную санкцию - князь обещал посоветоваться с панами-радой о наказании. Позже в Статутах XVI в. устанавливались более жесткие санкции относительно таких деяний.

Статуты Великого Княжества Литовского - государства, политикоэкономическим изентром которого стали белорусские земли, являли собой более совершенные, систематизированные нормативные акты. В них прослеживается явная и достаточно полная кодификация уголовного закона, хотя классификация уголовных деяний, которая основывалась прежде всего на объекте преступного посягательства, была ещё далека от совершенства. Тем не менее, уголовный закон активно развивался, о чем свидетельствует сравнительный анализ норм Статутов 1529, 1566 и 1588 годов.

Особенно видна хорошо разработанная система размещения уголовноправового материала в Статуте 1588 года11.

Так, самые тяжкие по мнению законодателя государственные преступления содержались в основном в разделе I «О персоне нашой господарской»; воинские преступления - в разделе II «О обороне земской»; преступления

10 Дагаворы і граматы як крыніцы беларускага феадальнага права. С. 110.

11 Статут Вялікага княства Літоускага 1588: Тэксты. Давед. Камент. / Беларус. Сав. Энцыкл.; Рэдкал.: І.П. Шамякін (гал. рэд.) [і інш.]. - Мінск: БелСЭ, 1989. - 573 с. 
против правосудия были сгруппированы в разделе IV «О судьях и о судех»; преступления против имущественных и личных прав, в том числе посягательство на личность (на ее жизнь, здоровье, честь, свободу), посягательство на личность и имущество (наезд, наход, разбой), посягательство на имущество (грабеж, кража, присвоение имущества, незаконное пользование и повреждение чужого имущества), а также нарушения постановлений, регулирующих взаимоотношения между феодалом и слугами, содержались в основном в разделах XI-XIV12.

Ученые по-разному классифицировали преступления, содержащиеся в Статуте 1588 года.

Так, И. А. Малиновский в зависимости от объекта посягательства выделял следующие виды преступлений: против веры, против морали, против семейного права, политические, воинские, преступления по судебной службе и против судебной власти, полицейские, преступления против чести, посягательства на личность, посягательства на личность и имущество, посягательства на имущество ${ }^{13}$. На тех же основаниях И. А. Юхо разделял преступления на: государственные, против порядка управления и правосудия, воинские, против религии и церкви, против морали, против жизни, здоровья и чести человека, посягательство на имущество, преступления слуг и феодальнозависимых людей против феодалов ${ }^{14}$.

Как видим, преступления против личности И. А. Малиновский и И. А. Юхо поместили на одно из последних мест.

Следует отметить, что и в самих Статутах преступления против жизни, здоровъя и чести мюдей были размещены законодателем в основном в последних разделах. При этом законодатель уделял им достаточно значительное внимание, пытаясь охватить все возможные стороны, варианты и обстоятельства совершения таких деяний: время, место, способ совершения, субъектный состав, отношение преступника и потерпевшего к преступлению и др.

Центром объекта данной категории преступлений являлась личность с принадлежащими ей правами, свободами и интересами. Анализируя составы таких преступлений, И. А. Малиновский разделял их на простые,

12 Малиновский И. А. Учение о преступлении по Литовскому Статуту / И.А. Малиновский. Киев: тип. Ун-та св. Владимира В.И. Заводского, 1894. С. 54.

13 Там же. С. 54.

${ }^{14}$ Юхо И. А. Правовое положение населения Белоруссии в XVI веке / И. А. Юхо. Минск: Изд-во БГУ им. В.И. Ленина, 1978. С. 84-85. 
квалифицированные, привилегированные и казуистические ${ }^{15}$. С этим стоит согласиться, однако придавая несколько иной, более современный смысл этим понятиям.

Непосредственным объектом преступлений против жизни являлась жизнь человека. При этом нормы Статута менее всего охраняли жизнь простых людей и почти вовсе не охраняли жизнь «выволанца» - лица, осужденного к изгнанию (р. XI, арт. 4), а также незаконнорожденного, при условии, что мать не воспользовалась правом взыскать головщину. Зародыш во чреве матери вовсе не являлся объектом преступления (р. XI, арт. 15).

Объективная сторона посягательства на жизнь выражалась в действиях: «струл» (отравил), «насмерть забил або яким обычаем о смерть приправил», «ранил, а где бы от тое раны умер» (причинил тяжкое телесное повреждение, повлекшее смерть потерпевшего). Законодатель отдельно рассматривал причинение смерти в драке, во время пытки, огнестрельным или холодным оружием, «здрадливым таемным обычаем» и др. Таким образом, он различал, что лишение жизни другого человека может быть совершено и неумышленно (в понимании законодателя - случайно или неосторожно). Можно предположить, что в случае, когда законодатель при описании объективной стороны не указывал на то, что данное преступление совершено неумышленно, значит это деяние являлось умышленным, т. к. характер действий указывал в данных случаях на волевую направленность деятельности субъекта.

Степень ответственности за убийство («забийство», «мужобойство») зависела от вины (умысел, неосторожность), мотива (ненависть, дерзость, «без данья причины своволно» и др.), цели, места совершения преступления (на княжеском дворе, на дороге и пр.), социального положения преступника и потерпевшего и ряда других обстоятельств. Все эти обстоятельства в отношении убийства законодатель в значительной степени относил к простым составам преступлений, хотя и различал простое убийство, убийство с отягчающими и со смягчающими вину обстоятельствами.

С отягчающими вину обстоятельствами признавались убийства:

а) сопряженные с причинением иного противоправного деяния (например, разбоя, наезда и др.);

б) оружием «до бою незвыклым»;

в) родителей, братьев и сестер;

г) мужа, совершенное совратителем жены;

${ }^{15}$ Малиновский И. А.Указ. соч. С. 112. 
д) совершенное «здрадливым потаемным обычаем»;

е) совершенное «з гнева або запаметолости»;

ж) убийство шляхтича, совершенное людьми «простого стану» 16 .

В качестве санкции за такие преступления предусматривалась, как правило, квалифицированная смертная казнь, выплата головщины в кратном размере (как правило, «совито», т.е. вдвойне) и кроме того для шляхтича - лишение чести. Так, убийство «здрадливым, потаемным обычаем» наказывалось для шляхтича «срогою смертью, четвертованием або на паль битьем», лишением чести и выплатой двойной головщины с имущества преступника. Простой человек за аналогичное преступление - «розными срогими муками з сего света зглажон будеть» (р. XI, арт. 17). Убийство шляхтича несколькими простыми людьми, даже совершенное во время ссоры, каралось смертью нескольких преступников (Статут 1566 г. - смертью семи человек; Статут 1588 г. ограничил ее применение - «не вышей трох человеков за одну голову шляхетскую» (р XI, арт. 39).

Особо строго наказывалось убийство родителей - «такою карностью, смертью ганебною маеть каран быти: по рынку возечи, клещами тело торгати, а потом в мех скуреный всадивши до него пса, кура, ужа, котку и тое все посполу в мех всадивши, и зашить и где наглубей до воды утопити» (p. XI, арт. 7). Н. С. Таганцев отмечал, что эта норма была взята с римского права 17 , только названия животных было приведено местное. Следует подчеркнуть, что в исследуемый период одно лишь оскорбление родителей, или настаивание из злости на осуждении родителей к смертной казни, или умышленное причинение им вреда наказывались весьма жестко.

Как правило, одинаковую ответственность несли все участники преступления, которые являлись соисполнителями. Так, за убийство шляхтича людьми «простого стану», как правило, все преступники наказывались смертью (р. ХI, ст. 39). Тем не менее, часто, особенно в связи с сословной принадлежностью человека, ответственность распределялась неравномерно. Например, за убийство шляхтича «в зваде», смертной казни подлежал один шляхтич или же трое простых людей, а остальные соучастники подвергались штрафу и тюремному заключению (р. ХI, ст.ст. 29, 39). При этом закон не регламентировал, на каком основании осуществлялся выбор.

Исходя из содержания ряда статей, некоторые составы преступлений можно было бы также отнести к убийству с отягчающими обстоятельствами

16Доӱнар Т.І. Указ. праца. С. 160.

${ }^{17}$ Таганцее Н. С. Преступления против жизни / Н. С. Таганцев. Т.ІІ. СПб. 1903. С. 43. 
(убийство сестры (брата); беременной женщины; доведение до смерти шляхтича, находящееся в причинной связи с незаконным самовольным лишением его свободы (р. XI, арт. 28); или же отнести к убийствам со смягчающими обстоятельствами (убийство родителями своего ребенка, убийство человека «перееждчого и безплеменного») 18 . Однако сам законодатель относил их к простым деяниям, о чем свидетельствуют санкции соответствующих статей. Кроме того, закон говорит о ненаказуемости убийства, совершенного в состоянии необходимой обороны, убийства вора на «горячим учинку» и разбойника на дороге, а также о возможности для преступника откупиться «пенезми» от наказания смертью или выхлопотать помилование «через приятелей своих або гостей, послов, панов знакомитых» (р. XI, арт. 20, 25, 56 и др.).

Вместе с тем, И. А. Малиновский выделял группу привилегированных убийств на том основании, что за их совершение была установлена меньшая ответственность.

С такой трактовкой можно согласиться, лишь указав, что законодатель исходил из принципа неумышленности действий преступника или невозможности вознаграждения близких потерпевшего. $\mathrm{K}$ ним И. А. Малиновский относил: детоубийство незаконнорожденного (р. XIV, арт. 32); убийство на поединке, дуэли (р. XI, арт. 14); убийство «шаленым» в период временного улучшения психического состояния; причинение смерти во время пыток (p. XIV, арт. 18); убийство при превышении пределов необходимой обороны (р. XII, арт. 1, 19, 20), а также случайное, неумышленное убийство (р. XI, арт. 23) $)^{19}$.

При этом, следует отметить, что закон почти не отличал неосторожность от случая и говоря о «неумысльном а пригодном мужобойстве», Статут перечисляет такие деяния и назначает за них, как правило, «головщину водле стану забитого» (XI, арт. 23). При этом законодатель, ориентируясь на сословное и служебное положение лица, устанавливал весьма различный размер головщины. Например, за шляхтича - 100 коп грошей, за простого человека в зависимости от его положения, служебных обязанностей и др. - от 2 коп до 60 коп грошей (р. XII, арт. 3-7).

В целом, в статутных нормах относительно преступных «учинков» прослеживается яркое проявление сословно-классового характера уголовного закона. Статут различал убийство шляхтича простым человеком, шляхтича

\footnotetext{
18 Доутнар Т. І. Указ. праца. С. 161.

${ }^{19}$ Малиновский И. А.Указ.соч. С. 148.
} 
шляхтичем, простого человека - простым, простого - шляхтичем. Жизнь и здоровье представителей сословия шляхты в значительно большей степени охранялась законом. Так, человек «простого стану» за убийство шляхтича подвергался смертной казни и двойной «головщине», а шляхтичу за такое убийство назначалась только «головщина» в одинарном размере. При этом, для наказания смертью простого человека достаточно было присяги истца с тремя свидетелями (Статут 1588, р. XII, арт. 2). Слуга, убивший своего хозяина, подвергался квалифицированному виду смертной казни - четвертованию. Если убийство шляхтича совершала в «зваде» группа шляхтичей, то смертной казни подвергался только один шляхтич из числа уличенных в убийстве.

В отношении таких преступлений против личности как посягательство на телесную неприкосновенность человека, следует подчеркнуть, что нормы Статутов не содержат описания объективной стороны таких деяний, а только называют такие деяния словами: «збил», «зранил», «утял», «урезал» и др. Основания выделения квалифицированных преступлений рассматриваемой группы такие же, как и оговоренные при рассмотрении убийств. Исходя из анализа содержания статей, такие деяния можно разделить по степени тяжести на тяжкие, менее тяжкие и легкие телесные повреждения ${ }^{20}$.

Наиболее разработанными в этом плане были положения Статута 1588 года. Так, законодатель одновременно с классификацией преступлений по объекту посягательства разделял их в Статуте на «речи крвавые, где о горле идеть» и на «речи меньшие, не крвавые, где о горле не идеть», т.е. классифицировал их по степени тяжести (опасности). В одной из статей был приведен и примерный перечень «речей крвавых»: убийство, разбой, изнасилование, поджог, наезд, сопряженный с убийством, после чего законодатель уточнял - «и иншие речи крвавые, то есть за што горлом карають» (р. IV, ст. 35). Все это дает основание считать, что приведенное деление на «речи крвавые» и «речи меньщие» соответствуют современным определениям тяжких и менее тяжких преступлений ${ }^{21}$.

В целом, относительно степени тяжести телесных повреждений в Статуте говорится о членовредительстве («вытятье або выбитье члонку»), увечьи

\footnotetext{
20 Доутнар T.I. Указ. праца. С. 162.

21 Доуннар Т. І. «Рэчы крывавыя». Рэчы меншыя / Т. І. Доўнар // Статут Вялікага княства Літоускага 1588: Тэксты. Давед. Камент. / Беларус. Сав. Энцыкл.; рэдкал.: І. П. Шамякін (гал. рэд.) і інш. Мінск: БелСЭ, 1989. С. 524.
} 
(«охроменьи»), причинении «ран значных», «значных и шкодливых», «обличных на твари», «крвавых в голове» и др. Отдельно законодатель выделяет побои. Членовредительство и причинение «значных ран» рассматривалось законодателем как самостоятельный состав преступления и как отягчающее вину обстоятельство. Умышленное членовредительство («которому шляхтичу або шляхтянке руку, ногу, нос, ухо, губы утял або урезал так, жебы праве проч который с тых члонков отпал або бы око, зубы вытял або выбил., албо на око ослепил... а естли бы обедве руки, ноги и ободва уха утял або обедве ока вытял або выбил... , а естли бы палец, колко их у руки або ноги утял...» и др.) наказывалось по принципу талиона. Закон прямо указывал: «за кождый члонок утятый або урезаный, або выбитый тому, хто в том винен зостанеть, маеть теж таковый члонок утят и урезан або выбит бытии» (р. XI, арт. 27).

За умышленное причинение ран шляхтичу шляхтичем назначалось тюремное заключение и штаф в зависимости от тяжести повреждений (за «рану обличную» - 40 коп грошей, «крвавую» - 30 коп грошей), за иные ранения «якою колвек бронью железною звычайною, ку бою заданые» - 20 коп грошей (р. XI, арт. 27). Квалифицирующим признаком и отягчающим обстоятельством считалось причинение телесных повреждений шляхтичу не боевым оружием, а ножом, кинжалом и пр. (р. XI, арт. 16, 27). Применение при причинении телесных повреждений «корда, меча, шабли и якое кольвек брони» трактовалось законодателем как причинение ран, а использование «кия, пуги, дубца» - как побои. Классовый подход при назначении наказания проявлялся, например, $b$ том, что простой человек за причинение членовредительства шляхтичу подвергался смертной казни, а шляхтич за аналогичное преступление $b$ отношении простого человека, при отсутствии квалифицирующих признаков, платил только штраф. В случае, если шляхтича побьет или просто «рукою на него сягнеть» простой человек, последний наказывался отсечением руки. Шляхтич же за такие деяния наказывался только штрафом (навязкой) (р. XI, арт. 39, 49, 81 и др.).

В Статуте говорилось также о «пакутах», морении лица голодом и о причинении таких легких телесных повреждений как пощечина, вырывание волос и бороды. Следует отметить, что причинение легких телесных повреждений - пощечина, рвание волос и бороды, толчок рукой (р. X1, арт. 27) законодатель часто связывал с унижением чести человека, особенно, если пощечина или рвание бороды и волос были совершены публично, т.к. считал, что такое деяние совмещает в себе покушение на честь и достоинство шляхтича. Соответственно этому устанавливалось достаточно строгое 
наказание - три недели тюрьмы и двенадцать рублей грошей, а за аналогичное преступление в отношении женщин-шляхтянок - следовало двойное наказание («совито») (р. XI, арт. 27).

Закон регламентировал и другие преступления против шляхетской чести. Так, в Статуте был предусмотрен особый состав такого правонарушения, когда оскорблением являлись сказанные кем-либо слова о том, что данное лицо не является шляхтичем. За такое правонарушение следовало наказание в виде тюремного заключения на двенадцать недель и штрафа (навязки) в двойном размере (р. III, арт. 19 ). Кроме того, в случае, если кто сказал следующие лживые слова: «жесь ты неучстивое маткеи и нечистого ложа сын», а не доказал этого в суде и суд соответственно признал оскорбленного «природным а правдивым шляхтичом», следовало наказание в виде штрафа в двойном размере (сорок коп грошей), а также публичное объявление о лживости заявления - произнесение слов «на тебе брехал яко пес» (р. III, арт. 28).

Таким образом, законодатель особо заботился об охране свободы и чести лиц, принадлежащих к шляхетскому сословию. При этом следует особо подчеркнуть, что в целом деяния, посягающих на честь личности, признавались преступными только в том случае, когда были направлены против лиц «шляхетского стану». Отметим при этом, что к сословию шляхты принадлежали все феодалы, включая и духовенство (p. XI, арт. 27). Объективная сторона таких преступлений проявлялась в произношении оскорбительных слов, а также иногда и совершении оскорбительных действий. Унизительные для чести слова, названные законодателем «голыми словами», должны были быть произнесены «очевисте», т.е. в присутствии оскорбленного. Иногда в статьях Статута лишь указывалось: «зельжил» (обесчестил), «обельжоно» и др., т.е. лицо было обесчещено или опозорено. Последними двумя терминами обозначалось, по нашему мнению, оскорбление действием. Признать какие-либо действия оскорбительными входило в компетенцию суда ${ }^{22}$.

Во всех трех Литовских Статутах заметно расширяется и в некоторой мере совершенствуется правовая охрана личной свободы человека. В них прослеживается стремление законодателя предупредить посягательства на личную свободу отдельных категорий лиц посредством нормативного ограничения случаев утраты личной свободы (ст. 12, разд. ХІ Статута 1529 г., ст. 13, разд. ХII Статута 1566 г., ст. 21, разд. ХІІ Статута 1588 г.).

22Доуннар Т. I. Указ. праца. С. 163. 
При этом, ответственность за посягательства на чичную свободу человека дифференцировалась в зависимости от сословной принадлежности потерпевшего. Прежде всего в законе закреплялась достаточно прогрессивная, как в технико-юридическом отношении, так и в плане содержания, норма об ответственности за посягательство на личную свободу шляхтича (р. XI, арт.28 Статута 1588 г.). Гарантируя лицам шляхетского положения свободы и вольности, а также защиту от преступных посягательств, в том числе и со стороны должностных лиц государства, закон провозглашал: «абы шляхтич невправне не был иман или сажон» (р. III, арт. 10). Противозаконное самовольное лишение свободы шляхтича рассматривалось законодателем как посягательство на личность и честь шляхтича и она могла произойти только «межы стану народу шляхетского» (р. XI, арт. 28). В этой статье сказано, что задержание шляхтича может совершаться как тайно, так и открыто, а также описаны почти все возможные варианты содержания под стражей и возможные последствия таких самовольных действий преступника, т.е. подробно описывается объективная сторона такого «свовольного везенья» и его последствий, соответственно чему устанавливались и санкции. Так, в случае смерти незаконно удерживаемой особы регламентировалась смертная казнь виновного и выплата «головщизны и шкоды».

Кроме того, предупреждая беззаконные действия в отношении шляхтича, закон достаточно четко регламентирует порядок задержания преступниковшляхтичей, запрещая при этом содержать их в самовольном заключении более суток («через день и через ноч») под угрозой выплаты навязки «водле стану» (р. XIV, арт. 21).

В отношении простых людей устанавливался запрет обращать в вечную неволю свободного человека за совершенное им преступление (ст. 6, разд. XI Статута 1529 г., ст. 7, разд. ХІІ Статута 1566 г., ст. 11, разд. ХІІ Статута 1588 г.).

Вместе с тем, будучи законами феодального периода, Статуты не были лишены сословно обусловленных начал ограниченности нормативных предписаний. Так, несмотря на декларирование приниипа единства права для всех ^юдей (ст. 1, разд. I Статута 1588 г.), в законе закрепляются юридические гарантии прав и привилегий лишь представителей шляхетского сословия. В области уголовно-правовой охраны личной свободы указанное положение проявилось в том, что свобода отдельных категорий населения по-прежнему признавалась предметом гражданско-правовых сделок (купли-продажи, особого вида залога и т.д.). Это находит подтверждение в нормах статьи 10 раздела ХІ Статута 1529 года («если бы кто-нибудь продал в рабство своего сына или свободного человека»), статьи 19 раздела XII Статута 1588 года («о свободных людях, 
которые во время голода продают себя в неволю, и о продаже иной челяди невольной»), статьи 22 раздела ХІІ Статута 1588 года («если бы кто кому передал слугу, а тот слуга, причинив вред, убежал бы от него») и др.

В то же время, особый юридический интерес представляют преступления против общественной нравственности. В связи с требованием законодателя, чтобы все люди «учстиве жили» в соответствии с законом Божьим и человеческой моралью, посягательство на духовные и нравственные устои общества законодатель считал злом «которым неменей пан Бог бывает ображон», поэтому и устанавливает ответственность за его совершение. Родовым объектом этой категории преступлений выступала общественная мораль.

В отношении изнасилования законодатель не обращает внимания на общественное положение потерпевшей, а сосредоточивает его на объективной стороне преступления: «усильством згвалтовал», «оная ... за оным учинком волала гвалту» и др., и назначает в качестве меры наказания смертную казнь и выплату навязки с имения виновного (Статут 1588, p. XI, арт. 12). Однако закон требует достаточных доказательств совершения преступления (свидетельских показаний 2-3 человек и др.). При этом в законе имелась оговорка: «естли бы она (т.е. потерпевшая) хотела его собе за мужа мети, то будеть на ее воли» (XI, арт. 12).

При регламентации прелюбодеяния законодатель вводит, исходя из сложности расследования такого вида преступлений, как и в случае изнасилования, определенные процессуальные гарантии против фальсификации доказательств и устанавливает за него высшую меру наказания (р. XIV, арт. 30).

В отношении сводничества, которое проявляется в подстрекательстве женщин к распутному образу жизни, законодатель также регламентирует жесткие санкции - изгнание сводниц с населенных пунктов с предварительным отрезанием носа, ушей, губ, а при рецидиве - смертную казнь. При этом закон обязывает местную администрацию заботиться об общественной нравственности и активно выявлять случаи сводничества (р. XIV, арт. 31).

Кроме того, вступление в брак с нарушением установленных законом условий (против воли родителей, вдовы до истечения шестимесячного срока после смерти мужа, двоеженство, а также лиц, состоявших в недозволенных степенях родства) наказывалось, как правило, лишением наследства, хотя в некоторых случаях предусматривались более жесткие санкции (Статут 1588, p. $\mathrm{V}$, арт. 8, 9, 13, 22). 
Умышленное избавление женщины от плода приводило к наказанию смертью не только «таких невест збытечных», но и тех, кто помогал в этом (р. XI, арт. 60).

Впервые в статутных нормах регламентировалась ответственность за похищение женщины с целью вступления в брак (ст. 9, разд. ХІ Статута 1566 г., ст. 13 разд. XI Статута 1588 г.). Такого рода деяния можно рассматривать не только как преступления против общественной нравственности, но и как посягательства на свободу женщины. Так, за насильственный брак с женщиной преступник мог быть наказан смертью, а треть его имущества передавалось потерпевшей. Кроме того, понесенный от преступления ущерб выплачивался с остальных двух третей имущества преступника.

Закон регламентировал и другие преступные деяния относительно женщин. Так, при краже замужней женщины с целью сделать ее женой при ее согласии - оба карались смертью, кроме случая, когда «муж ее горлом карати не хотел». Если же при побеге был убит преступник или муж, закон требовал рассматривать преступление по аналогии с прелюбодеянием.

Наличие в статутном законе рассмотренных выше составов преступлений свидетельствовало о стремлении законодателя охватить все возможные случаи противоправных деяний против личности и установить единообразие в применении наказаний за них. Хотя регламентация отмеченных преступлений в XVI в. была еще далека от совершенства, т.к. в нем отсутствовала должная последовательность и системность, а статутным нормам была свойственна некоторая казуальность, дробность различных оттенков преступных деяний, иногда неопределенность признаков составов преступлений, в целом уголовный закон характеризовался сравнительно высокой для своего времени развитостью. В нем явно прослеживалось стремление законодателя обеспечить законность и справедливость в отношении преступления и наказания, в том числе в сфере уголовно-правовой охраны жизни, здоровья, чести и личной свободы человека.

Dr. habil. Prof. Taisa Dovnar (Minsk, Belarus)

Formation and Development of Normative Regulation of Crimes Against Person in Medieval Belarus

In ancient times the custom was to regulate relations in the sphere of protection of the individual. Gradually, it was replaced by written law (Rus Pravda, princely charters, international treaties, etc.), which, however, contained only certain criminal law norms. Later, in the Grand Duchy of Lithuania, the political and economic centre 
of which was the Belarusian lands, the criminal law was improved and systematized, as evidenced by the Forensic of 1468 and the Statutes of 1529, 1566, 1588. Analyzing the components of criminal acts in the sphere of criminal law protection of life, health, honour and personal freedom, the author, noting some shortcomings of the criminal law of the XVI century, concludes that the legislator seeks to ensure its legality and justice, as well as to cover all possible cases of unlawful acts against the individual, systematize them, establish uniformity in the application of punishments and clear differentiation of sanctions in connection with the severity of crimes and other circumstances.

Key words: Custom, Criminal Law, Systematization, Statute of 1588, Crimes against a Person, Punishment.

Профессор Таисия Довнар (Минск, Беларусь)

Становление и развитие нормативной регламентации преступлений против личности в Средневековой Беларуси

В древний период обычай регулировал отношения в сфере охраны личности. Постепенно на смену ему приходит писаный закон (Русская Правда, княжеские уставы, международные договоры и др.), который, однако, содержал лишь отдельные уголовно-правовые нормы. Позже, в Великом княжестве Литовском, политико-экономическим центром которого стали белорусские земли, уголовный закон совершенствуется и систематизируется, о чем свидетельствуют Судебник 1468 г. и Статуты 1529, 1566, 1588 гг. Анализируя составы преступных деяний в сфере уголовно-правовой охраны жизни, здоровья, чести и личной свободы человека, автор, отмечая некоторые недостатки уголовного закона XVI в., делает вывод о стремлении законодателя обеспечить законность и справедливость, а также охватить все возможные случаи противоправных деяний против личности, систематизировать их, установить единообразие в применении наказаний и четкую дифференциацию санкций в связи с тяжестью преступлений и иными обстоятельствами.

Ключевые слова: обычай, уголовный закон, систематизация, Статут 1588 г., преступления против личности, наказание. 
Професор Таїсія Довнар (Мінськ, Білорусь)

Становлення i розвиток нормативної регламентації злочинів проти особистості в Середньовічній Білорусі

У давнину звичай регулював відносини в сфері охорони прав і свобод особистості. Поступово на зміну йому приходить писаний закон (Руська Правда, князівські статути, міжнародні договори та ін.), що, однак, містив лише окремі кримінально-правові норми. Пізніше, у Великому князівстві Литовському, політико-економічним центром якого стали насамперед білоруські землі, кримінальний закон вдосконалюється і систематизується, про що свідчать Судебник 1468 року і Статути 1529, 1566, 1588 рр. Аналізуючи склади злочинних діянь у сфері кримінально-правової охорони життя, здоров'я, честі та особистої свободи людини, автор, відзначаючи деякі недоліки кримінального закону XVI ст., робить висновок про прагнення законодавця забезпечити законність і справедливість, а також охопити всі можливі випадки протиправних діянь проти особистості, систематизувати їх, встановити однаковість в застосуванні покарань і чітку диференціацію санкцій у зв'язку з тяжкістю злочинів та іншими обставинами.

Ключові слова: звичай, кримінальний закон, систематизація, Статут 1588 р., злочини проти особистості, покарання.

* Довнар Таисия Ивановна - доктор юридических наук, профессор, профессор кафедры теории и истории государства и права Белорусского государственного университета.

E-mail: dovnar-taisa@rambler.ru 